\title{
Strategies to reduce reliance on soya bean meal and palm kernel meal in livestock nutrition
}

\author{
J.M. Wilkinson ${ }^{1 *}$ and R.H. Young ${ }^{2}$ \\ ${ }^{1}$ School of Biosciences, Sutton Bonington Campus, University of Nottingham, Loughborough, LE12 5RD, United Kingdom; \\ ${ }^{2}$ Sustainable Food Trust, 38 Richmond Street, Totterdown, Bristol, BS3 4 TQ, United Kingdom; j.mike.wilkinson@gmail.com
}

Received: 16 April 2020 / Accepted: 4 June 2020

(c) 2020 J.M. Wilkinson et al.

REVIEW ARTICLE

MULTI-SPECIES

\begin{abstract}
Greenhouse gas emissions and loss of wildlife habitats have stimulated growing global concern over the continued expansion of soya bean and palm oilseed production on land recently converted from forest and natural grasslands. This paper reviews the roles of soya bean meal and palm kernel meal in livestock nutrition, drawing on research data to explore the potential for their replacement in nutritionally balanced diets. Soya bean meal is a widely used livestock feed due to relatively high levels of total protein and essential amino acids. Palm kernel meal has been used for many years in compound feeds for ruminant livestock and as a supplement to grazed pasture in periods of drought. A range of alternative sources of protein is available to replace soya bean and palm kernel meals, e.g. protected rapeseed meal can replace soya bean meal in diets for productive dairy cows, but constraints to widespread adoption include insufficient supply, anti-nutritional factors which require feeds to be processed or supplemented with enzymes, and imbalances in essential amino acids. Soya 'milk' made directly from soya beans is a less efficient process than producing milk from dairy cows, especially when they are grazed on pastures or given diets that do not contain soya bean meal.
\end{abstract}

Keywords: protein, feeds, foods, milk, environment

\section{Introduction}

There is widespread concern about increasing global production of soya bean and palm oils, which doubled between 2000/01 and 2018/19 (Statista, 2019a) and is associated with deforestation, soil degradation, destruction of wildlife habitats, and the loss of natural grasslands in some regions of the world. In response, the Round Table on Sustainable Palm Oil (RSPO) was established in 2004, followed by the Round Table on Responsible Soy Association (RRSA) in 2006. The aim of these associations was to encourage certification of sustainable production, processing, and use, through national commitments, but these have had varying degrees of success (RRSA, 2019; RSPO, 2019). For example, Cargill warned in June 2019 that global private sector companies would not fulfil their target, endorsed in 2014 as Goal 2 of the New York Declaration on Forests (NYDF, 2019), to eliminate deforestation from production of agricultural commodities by 2020 (Meyer and Schipani, 2019).

Soya bean and palm oils together comprise about $90 \%$ of total world vegetable oil production (OECD/FAO, 2019). Soya oil is used widely in human foods (Gunstone, 2003), as is palm oil, but palm kernel oil, from the seed of the oil palm fruit, is used mainly in detergent and cosmetic products with only limited use in human foods (Berger, 2003). Soya beans and palm kernels are crushed mechanically to expel oil. Meals remaining after expelling are known as 'expeller' meals. Expelling may be followed by solvent extraction of residual oil, and the solid fraction remaining is known as 'extract' meal. 
Large quantities of oilseed meals are imported into the European Union (EU) for use as animal feed. The EU is only $5 \%$ self-sufficient in soya bean meal compared to $79 \%$ self-sufficiency for rapeseed meal (FEFAC, 2017). Oilseed meals account for around $50 \%$ of all imported feed materials used for compound animal feed production in the EU. Imports of soya bean meal into the EU in 2018/19 totalled 15.1 million tonnes, of which 9.1 million tonnes was from the USA and 4.8 million tonnes was from Brazil (European Commission, 2019). This represented 7.4 million hectares of land, assuming a typical fresh weight ratio of $48 \%$ crude protein $(\mathrm{CP})$ soya bean meal to whole soya beans of $0.73: 1$ (CME Group, 2020), and an average yield of 2.8 tonnes of soya beans per hectare (FAO, 2020).

Imported soya bean meal into the UK amounted to 2.0 million tonnes in 2018/19, of which 1.1 million tonnes was used for animal feed production (AHDB, 2019), with the remainder presumably used in human foods, pet foods and non-food products. Furthermore, significant quantities of soya bean meal are imported indirectly into the EU and UK via livestock products derived from animals given soya bean meal in their diets in their country of origin.

Palm kernel meal is imported into the EU and is also produced in Europe from imported palm kernels. There are no data for palm kernel meal production and use in the EU because it is included with 'other' oilseed meals in EU statistics. However, data exist for the UK which show that 34,064 tonnes of palm kernel meal was imported in 2018/19. Production of meal from imported palm kernels amounted to 0.49 million tonnes in 2018/19 (AHDB, 2019). It can be assumed that virtually all palm kernel meal is consumed as animal feed, with small quantities used as a raw material for other processes, such as protein extraction (Arifin et al., 2009).

This review covers the use of soya bean and palm kernel meals as livestock feeds. Alternative sources of dietary protein are discussed with the objective of reducing reliance on soya bean and palm kernel meals in livestock nutrition. The efficiency of soya bean use for the production of either soya drink (also known as 'soya milk' or 'soymilk' outside the EU) or dairy cow milk is compared. The relative efficiencies of different livestock systems, in terms of converting human-edible and inedible feeds into human-edible animal products, have been discussed elsewhere (CAST, 1999; Wilkinson, 2011; Wilkinson and Lee, 2018) and are not considered in this paper.

\section{Composition of protein-rich animal feeds and human foods}

The key nutrient in both soya bean and palm kernel meals is protein, defined as CP which is calculated from total nitrogen $(\mathrm{N}) \times 6.25$. However, both feed sources also provide the animal with energy. The energy value of most protein-rich feeds is relatively high, indicating that these materials fulfil the two most important roles in nutrition in supplying both amino acids and energy to sustain the bodily functions of metabolism, growth, pregnancy and lactation.

Concentrations of $\mathrm{CP}$ and energy of some protein-rich animal feeds and human foods of vegetable origin are shown in Table 1. Animal feeds are made up of ingredients as concentrates, which comprise the total diet of monogastric livestock (e.g. pigs and poultry) and as supplements to silage, hay and grazed pasture for ruminants at certain stages of the production cycle when nutrient requirements are higher, e.g. early lactation, late pregnancy and the finishing period of beef cattle.

Comparing animal feeds in Table 1, the CP content of expelled palm kernel meal is lower than that of other protein-rich feeds, and its energy value is lower than most other feeds, with the exception of dried lucerne (alfalfa, Medicago sativa) and ensiled brewers' grains (Hordeum vulgare). The highest levels of CP in crop-derived animal feeds are found in soya bean and maize gluten meals, reflecting the relatively high proportion of seed embryo in these meals. The CP and energy levels of peas and beans are intermediate to other animal feeds. For comparison, average levels of $\mathrm{CP}$ and metabolisable energy (ME) in a study of 8,814 samples of pre-grazed pasture grass (i.e. sampled prior to being grazed) in the UK were $214 \mathrm{~g}$ $\mathrm{CP} / \mathrm{kg}$ dry matter (DM) and 11.7 MJ ME/kg DM (Wilkinson et al., 2014).

Comparing examples of protein-rich human feeds in Table 1 , the energy values of peanut butter and pumpkin seeds reflect their high levels of oil ( 524 and $483 \mathrm{~g} / \mathrm{kg}$ DM, respectively). Soya drink typically has a higher level of protein, but is lower in energy than dairy cow milk.

\section{Environmental issues}

The continued production of soya beans and palm oil on land converted from rain forest, with the ongoing destruction of wildlife and human habitats, is a serious environmental issue. Soya bean meal has a very high carbon footprint if it is derived from crops grown on land recently converted from forest or savannah (see detailed analyses by Castanheira and Freire, 2013 and Opio et al., 2013). The cultivation and consumer acceptance of genetically modified (GM) soya bean crops are issues in some regions, especially Europe (Lucht, 2015). Increased global demand and legislative restrictions on the importation of GM soya beans into the EU from North America initially stimulated production in South America, on land which was previously rain forest or savannah. 
Table 1. Typical levels of crude protein and energy in some protein-rich animal feeds (Feedipedia, 2019) and human foods (Public Health England, 2019).

$\begin{array}{llc}\text { Animal feeds } & \text { Crude protein (g/kg DM) } & \text { Energy }{ }^{1} \text { (MJ/kg DM) } \\ \text { Palm kernel meal (Expeller, Attalea spp., Elaeis spp.) } & 167 & 11.6 \\ \text { Dried lucerne (Medicago sativa) } & 227 & 9.3 \\ \text { Peas (Pisum sativum) } & 239 & 13.4 \\ \text { Beans (Vicia faba) } & 290 & 13.3 \\ \text { Brewers' grains (Ensiled, Hordeum vulgare) } & 292 & 13.1 \\ \text { Distillers' dark grains with solubles (Wheat, Triticum aestivum) } & 314 & 13.1 \\ \text { Rapeseed meal (Canola meal, expeller, Brassica napus) } & 337 & 14.8 \\ \text { Lupins, white (Lupinus albus) } & 379 & 13.2 \\ \text { Cottonseed meal (Expeller, Gossypium spp.) } & 450 & 14.0 \\ \text { Groundnut meal (Peanut meal, expeller, Arachis hypogaea) } & 491 & 13.6 \\ \text { Soya bean meal (High protein, dehulled, Glycine max) } & 535 & 16.6 \\ \text { Maize gluten meal (Prairie meal, Zea mays) } & 672 & \text { Energy }{ }^{2} \text { (MJ/kg DM) } \\ & & 25.4 \\ \text { Human foods } & \text { Crude protein (g/kg DM) } & 24.8 \\ \text { Peanut butter (Arachis hypogaea) } & 231 & 9.9 \\ \text { Pumpkin seeds (Pepita, Cucurbita pepo) } & 258 & 14.2 \\ \text { Spinach (Spinacia oleracea) } & 272 & 16.4 \\ \text { Lentils (Red, Lens culinaris) } & 283 & 15.4 \\ \text { Wheatgerm (Triticum aestivum) } & 300 & 21.4 \\ \text { Soya drink (Glycine max) } & 343 & 274 \\ \text { Dairy cow milk, whole (Bos taurus) } & & \end{array}$

2 Gross energy, calculated from protein, fat and carbohydrates.

In contrast, soya bean crops on land that has been in arable cultivation for many years have a relatively low carbon footprint per unit of protein compared to other arable crops, mainly because the land has already lost a significant amount of its organic matter and the soya bean plant is a legume, which traditionally does not receive fertiliser nitrogen (Audsley and Wilkinson, 2014). Additional fertiliser nitrogen inputs are, however, recommended where soya bean yields are predicted to exceed $4 \mathrm{t} / \mathrm{ha}$ (Schmidt, 2019).

Nitrogen excretion by livestock in faeces and urine is an environmental issue, resulting in emissions of nitrous oxide into the air and ammonia and of nitrate to water courses. The importation of 15 million tonnes of soya bean meal into the EU in 2018/19 represented an additional input of 1 million tonnes of $\mathrm{N}$ to the livestock industry. Assuming an average $30 \%$ efficiency of $\mathrm{N}$ use ( $\mathrm{N}$ in animal product as a percentage of $\mathrm{N}$ intake) by dairy cows, pigs and poultry (Wilkinson and Audsley, 2013), some 700,000 tonnes of N from the soya bean meal imported into the EU in 2018/19 is likely to have been excreted via livestock manure to soil, water and air.

In a modelling study, in which a range of different concentrates was included in diets to meet metabolisable energy and protein requirements for a dairy cow yielding 40 litres of milk daily, ingredients selected for lowest possible total carbon footprint included soya bean meal, even though its carbon footprint was higher than that of alternative feeds. The diet formulation included soya bean meal because its protein concentration and ratio of digestible undegraded protein (DUP) to carbon footprint were higher than other feeds (Wilkinson and Garnsworthy, 2016).

Nevertheless, the continued trend of deforestation and removal of natural grasslands to create more arable land for soya bean and palm oil production has focussed attention on the urgent need for the animal feed and human food industries to replace soya bean and oil palm products with alternative sources of protein-rich ingredients. In the following sections, certain research findings are presented to illustrate the potential for replacing soya bean meal and palm kernel meal in diets for livestock.

\section{Soya bean meal}

\section{Why is soya bean meal used?}

Soya bean meal is used widely in livestock nutrition and is often the preferred choice of animal nutritionists when formulating diets because of its relatively high $\mathrm{CP}$ and essential amino acid content, compared to other proteinrich feeds. Diets for poultry and pigs are comprised predominantly of cereal grain, with soya bean meal as the main source of protein (Wilkinson, 2011). The higher the concentration of $\mathrm{CP}$ in a particular feed, the less weight has to be included in a diet to meet the nutritional specification of the diet, creating space for other, lower cost, feeds to be included in the formulation.

Typical levels of inclusion of soya bean meal in diets for poultry, pigs and housed cattle are shown in Table 2. Diets 
for poultry and pigs contain higher levels of soya bean meal than those for ruminant livestock. Diets for sheep typically do not contain soya bean meal, but may contain palm kernel or rapeseed meal as protein sources. Many dairy and beef cattle, especially those managed in organic and biological systems and in $100 \%$ grass-based systems, receive no soya bean meal at all.

Small amounts of soya bean oil are included in pig and poultry feeds, but its main uses are in processed foods and production of inks, paint and cosmetics (Scott Wilson, 2006). The UK, for example, imported 179,231 tonnes of soya bean oil in 2017/18 (AHDB, 2019) which had been produced from approximately 1.2 million tonnes of whole soya beans, leaving approximately 1 million tonnes of soya bean meal for livestock feed or other uses. Additional oil may be produced from whole soya beans imported into the UK, which averaged approximately 750,000 tonnes per annum recently (AHBD, 2019), but precise statistics are lacking.

Additionally, soya bean meal is present in human foods, although statistics are lacking for levels of use. De-hulled soya bean meal, processed into high-protein flour, is used in a wide range of human foods including breads, cakes, cereals, pasta products, soups, dairy substitutes, tofu, and textured vegetable protein (Van Gelder and Dros, 2002; Shurtleff and Aoyagi, 2004). Soya flour may be included with wheat flour at up to $120 \mathrm{~g} / \mathrm{kg}$ total fresh weight, with little change in the physical and sensory properties of bread (Traynham, 2006). Soya flour is also used together with maize flour in gluten-free bread.

\section{Alternatives to soya bean meal}

Research into alternatives to soya bean meal for livestock has focused mainly on its replacement by other oilseed meals (e.g. rapeseed meal, sunflower meal) or pulses (peas and beans). Leinonen et al. (2013) compared the environmental impact of alternative protein crops in nutritionally-balanced poultry diets. They concluded that the reduction in global warming potential (GWP) following the substitution of soya bean meal by peas, beans or sunflower meal was possible, but the extent of the reduction in GWP depended on the method of land use change applied in the analysis. For

Table 2. Typical levels of soya bean meal in diets for housed European livestock (based on Karlsson et al., 2018; Kroes and Kuepper, 2015; Leinonen et al., 2013; White et al., 2015; Wilkinson, 2011).

\begin{tabular}{lc} 
Livestock system & Soya bean meal ( $\mathrm{g} / \mathrm{kg}$ total diet DM) \\
\hline Poultry meat & 220 \\
Egg production & 130 \\
Pigs & 130 \\
Dairy cows & 90 \\
Other cattle & 70
\end{tabular}

example, using alternative protein sources had only a small and non-significant effect on reducing GWP compared to using soya produced on land that had been in arable cultivation more than 20 years.

In a detailed review, Iji et al. (2017) concluded that several alternative feed sources had potential for use in poultry nutrition, ranging from other oilseed meals to algae and insects. Constraints to the utilisation of alternatives included inadequate volumes of supply, anti-nutritional factors requiring processing and/or enzyme addition, elevated levels of fibre or imbalances in essential amino acids, which reduced biological value. Consequently, without processing and/or supplementation with pure amino acids, alternatives were generally inferior and could only act as partial replacers for soya bean meal without reducing chicken growth rate or egg production.

Florou-Paneri et al. (2014) reviewed research findings for a range of alternative protein sources in pig diets, and concluded that soya bean meal may be replaced by sunflower or rapeseed meal in the grower and finisher phases, without reducing animal productivity or meat quality. White et al. (2015) reported that replacing soya bean meal (130 g/ kg total diet fresh weight) with pulses - peas (Pisum sativum, $300 \mathrm{~g} / \mathrm{kg}$ total diet fresh weight) or beans (Vicia faba, $300 \mathrm{~g} / \mathrm{kg}$ total diet fresh weight) - in nutrient-balanced diets for grower and finishing pigs had generally non-significant effects on feed intake, efficiency of nitrogen utilisation, growth rate or carcass traits (Table 3 ). Life cycle analysis of replacing soya bean meal with equivalent $\mathrm{CP}$ from rapeseed meal in diets for finishing pigs revealed decreases in GWP, energy use and land use (Van Zanten et al., 2015).

Comparisons for dairy cows between soya bean meal and alternative feeds have been made by formulating diets to be iso-nitrogenous and iso-energetic. Karlsson et al. (2018) compared a conventional cereal grain plus soya bean meal diet with diets containing distillers' dark grains and/or rapeseed meal as the protein-rich fraction. They found that complete replacement of soya bean meal with alternative protein sources was possible with cows in midlactation yielding $32 \mathrm{~kg}$ milk daily. Net food production (CP or energy), defined as the human-edible content of the milk produced daily minus the potential human-edible amount of feed consumed daily, was negative for the cereal grain plus soya bean meal diet but strongly positive for the diets that comprised alternative protein sources.

In a meta-analysis of 122 studies, Huhtanen et al. (2011) found that responses in DM intake and milk yield to increasing levels of diet total $\mathrm{CP}$ were significantly higher for rapeseed than for soya bean meal where grass silage was the basal forage component. Average levels of milk production in the dataset were less than $30 \mathrm{~kg} /$ day, suggesting that 
Table 3. Growth rate and feed conversion ratio of pigs given diets containing soya bean meal or pulse seeds as the main protein source (White et al., 2015).

\begin{tabular}{|c|c|c|c|c|}
\hline & Soya bean & Pulse & SED & $P$-value \\
\hline \multicolumn{5}{|l|}{ Grower phase (30 to $55 \mathrm{~kg}$ live weight) } \\
\hline Live weight gain (kg/day) & 0.92 & 0.98 & 0.035 & 0.027 \\
\hline Feed conversion ratio ( $\mathrm{kg}$ feed $/ \mathrm{kg}$ weight gain) & 1.92 & 1.87 & 0.834 & 0.481 \\
\hline \multicolumn{5}{|l|}{ Finisher phase ( 55 to $95 \mathrm{~kg}$ live weight) } \\
\hline Live weight gain (kg/day) & 1.13 & 1.15 & 0.482 & 0.226 \\
\hline Feed conversion ratio (kg feed/kg weight gain) & 3.05 & 2.97 & 0.811 & 0.430 \\
\hline
\end{tabular}

energy supply, rather than DUP, was the major factor limiting milk production and that responses to protein were most likely responses to additional metabolisable energy intake. Nevertheless, the authors concluded that the metabolisable protein concentration of soya bean meal was overestimated relative to rapeseed meal.

The challenge to using alternatives to soya bean meal is to meet requirements for DUP and metabolisable protein in high-yielding dairy cows. In this situation, total supply of essential amino acids from rumen microbial protein and DUP may be inadequate, due to extensive feed protein degradation in the rumen. Garnsworthy et al. (2019) examined the potential of using 'protected' expeller rapeseed meal, in which the protein is rendered more resistant to degradation in the rumen by heat and wood xylose treatment, in partial mixed rations for highyielding dairy cows formulated to meet energy and protein requirements for maintenance and the production of 32 litres of milk/day. A compound feed was given according to yield above 32 litres/day. The results of the trial are shown in Table 4. Milk yield was higher for cows given protected rapeseed meal than for cows given soya bean meal, indicating improved essential amino acid balance in the protected rapeseed compared to soya bean meal.

\section{Palm kernel meal}

\section{Why is palm kernel meal used?}

Historically, palm kernel meal was a major source of supplementary protein in diets for livestock because it was available in Europe in large quantities as a by-product of the soap and cosmetics industries. Boutflour (1967) described substantial milk yield responses to supplements

Table 4. Effect of replacing soya bean meal with rumen-protected rapeseed meal in dairy cow diets (Garnsworthy et al., 2019).

$\begin{array}{lllll} & \text { Soya bean } & \text { Rapeseed } & \text { SED } & P \text {-value } \\ \text { Feed intake }(\mathrm{kg} \mathrm{DM} / \text { day) } & 23.9 & 25.1 & 0.39 & 0.012 \\ \text { Milk yield }(\mathrm{kg} / \text { day) } & 41.1 & 42.8 & 0.57 & 0.009 \\ \text { Milk fat }(\mathrm{g} / \mathrm{kg}) & 35.1 & 34.5 & 0.16 & 0.448 \\ \text { Milk protein }(\mathrm{g} / \mathrm{kg}) & 32.9 & 32.5 & 0.16 & 0.004\end{array}$

of palm kernel cake by dairy cows given diets based on low protein hay. Relatively low levels of CP and essential amino acids, coupled with high fibre make palm kernel meal unattractive for use in diets for monogastric livestock. Boateng et al. (2008), reviewed the potential for including palm kernel meal in diets for growing poultry and pigs, and concluded that very low levels of dietary inclusion - up to $12.5 \%$ of total diet fresh weight for broiler chickens and up to $20 \%$ of total diet fresh weight for growing pigs - could sustain similar levels of production to conventional diets based on maize grain. The authors indicated that enzymic treatment of non-starch polysaccharides in palm kernel meal, especially the addition of beta-mannanase, could increase fibre digestibility.

Stein et al. (2015) highlighted the relatively low level of digestible energy in palm kernel meal and that 65 to $75 \%$ of the total phosphorus (P) it contains is bound to phytate. The authors noted, however, that supply of digestible $\mathrm{P}$ could be increased to levels similar to soya bean meal following addition of microbial phytase. Pig growth rate was similar following replacement of up to $15 \%$ of a maize grain/soy bean meal diet by palm kernel meal in diets balanced for digestible amino acids, P and ME (Jaworski et al., 2014).

There is evidence that palm kernel meal has relatively low palatability. Increased substitution of soya bean meal with palm kernel meal in isonitrogenous concentrates given to cows, together with low protein sugarcane (Saccharum officinarum), resulted in reduced total feed intake and milk yield at inclusion levels of palm kernel meal greater than 113 $\mathrm{g} / \mathrm{kg}$ total diet DM (Cunha et al., 2013). Dias (2010) found that total diet fibre digestibility was decreased when palm kernel meal was given together with high quality pasture grass, but not when used as a supplement to low quality pasture. Given its similarity in energy and protein levels to grass and its relatively low palatability, palm kernel meal is used in some regions (e.g. New Zealand) as a supplement to grazed pasture, especially in periods of drought and restricted pasture availability. However, the quality of the palm kernel meal available in this region varies widely, due to processing and origin. 
Dias et al. (2008) found that cows in late lactation given a restricted daily pasture allowance of $20 \mathrm{~kg} \mathrm{DM} / \mathrm{cow}$ responded in terms of milk yield to increased levels of palm kernel expeller meal but yields were lower than for cows given a higher daily pasture allowance of $40 \mathrm{~kg}$ DM/ cow (Table 5). Palm kernel meal was offered twice daily for about 40 minutes after milking, at either $3 \mathrm{~kg}$ or $6 \mathrm{~kg}$ fresh weight. Significantly, $40 \%$ of the palm kernel meal was refused when offered at $6 \mathrm{~kg} /$ day, but only $15 \%$ was refused at $3 \mathrm{~kg} /$ day, indicating a limit to voluntary intake of the meal when offered for short periods of time, possibly associated with its dry nature and/or low palatability.

Palm kernel meal is associated with an increase in total milk fat concentration (Van Wyngaard and Meeske, 2017). The fatty acid profile of palm kernel meal may make milk less suitable for processing into manufactured dairy products, due to reduced levels of total protein, elevated levels of total fat and increased proportions of saturated fatty acids, especially lauric acid (C12:0), in milk and cheese (Oliveira et al., 2015). It has been recommended, therefore, that the level of palm kernel meal in the diet of the dairy cow should be limited to a maximum of $3 \mathrm{~kg}$ fresh weight/day (New Zealand Farmers Weekly, 2015).

The level of CP in grazed pastures is typically in excess of the grazing animal's requirement, leading to excessive excretion of $\mathrm{N}$ in urine, elevated emissions of ammonia and nitrous oxide to the atmosphere (Frank and Swensson, 2002; Voglmeier et al., 2019), and the risk of nitrate pollution in water courses (Wilkinson and Waldron, 2017). For the same reasons, the $\mathrm{CP}$ in palm kernel meal is too high (Table 1) for its use to be condoned as a pasture supplement, and lower protein alternatives should be chosen.

\section{Alternatives to palm kernel meal}

Substitutes for palm kernel meal as a pasture supplement include low-protein feeds, such as rolled barley grain, rolled oats or cracked wheat grain, sugar beet pulp or maize silage. These feeds balance excess rumen-degradable protein from pasture grass and, by providing a readily-available supply of energy in the rumen, may enhance microbial protein production which can reduce excessive excretion of $\mathrm{N}$ in urine, thereby increasing $\mathrm{N}$ use efficiency (Wilkinson and Waldron, 2017). Where a higher protein level is required in the supplement, e.g. due to low levels of CP in mature pastures, rapeseed meal or distillers' dark grains would be appropriate alternative feeds.

\section{Dairy cow milk versus soya drink}

It has been claimed that consuming soya-extracted 'milk' drinks rather than feeding soya bean meal to cows to produce milk is more efficient in terms of soya use (Whiting, 2019). The yield of soya drink ranges from 4.25 to 7.5 litres per kg whole soya bean fresh weight, depending on the scale of operation (Young, 2017). Based on information from the UK Department for Environment, Food and Rural Affairs (Personal communication, 2017), it has been estimated that between 92,000 and 173,000 tonnes of soya bean meal is used in dairy cow diets in the UK (Young, 2017). Total milk production in the UK was 14,713 million litres in 2017/18 (Statista, 2019b), which can be calculated as the yield of dairy cow milk being 85 litres per kg soya bean meal consumed. Kroes and Kuepper (2015) calculated that $7 \mathrm{~g}$ of soya bean meal is needed to produce $200 \mathrm{ml}$ of dairy cow milk, or 28.6 litres per kg soya bean meal. The higher relative use of soya in European dairy farming compared with UK may reflect the greater abundance of grass growth in the latter. Therefore, it seems reasonable to assume that the yield of dairy cow milk in Europe is between four and 11 times higher than the yield of soya drink produced direct from soya beans, depending on the extent to which soya bean meal is used in dairy cow nutrition in different regions. A further consideration is that dairy cow milk is made from the meal co-product of soya oil production, with little residual oil, whereas soya drink is made from whole beans.

The trend towards more milk and meat from pasturefed cattle and free-range poultry production in Europe in response to increased consumer demand for natural livestock products (Wilkinson et al., 2020), should result in reduced demand for soya bean meal in future years.

\section{Conclusions}

Soya bean meal and palm kernel meal are important sources of supplementary protein for livestock, but there are serious environmental issues around their increased production on land converted from forest and natural grasslands. There is much research into alternative protein sources, illustrating the considerable potential to replace soya bean meal and palm kernel meal in livestock diets.

Table 5. Effect of supplementing grazing dairy cows in late lactation with palm kernel expeller meal (Dias et al., 2008).

\begin{tabular}{|c|c|c|c|c|c|c|}
\hline \multirow[b]{3}{*}{ Estimated pasture intake (kg DM/day) } & \multicolumn{4}{|c|}{ Daily pasture allowance } & \multirow[t]{2}{*}{ SED } & \multirow[t]{2}{*}{$P$-value } \\
\hline & \multicolumn{3}{|c|}{ Restricted (20 kg DM/cow) } & \multirow{2}{*}{$\begin{array}{l}\text { Ad libitum (40 kg DM/cow) } \\
12.5\end{array}$} & & \\
\hline & 8.8 & 8.3 & 7.1 & & 1.45 & $<0.05$ \\
\hline Est. palm kernel meal intake (kg DM/day) & - & 2.55 & 3.63 & - & 0.46 & - \\
\hline Milk yield (kg/cow/day) & 7.3 & 8.3 & 9.1 & 11.4 & 0.30 & $<0.05$ \\
\hline
\end{tabular}


However, constraints regarding the use of alternatives, including inadequate supply and anti-nutritional factors, must be addressed to fulfil their potential. Milk produced from dairy cows given diets containing soya bean meal is a more sustainable use of land than producing human drink products directly from soya beans, especially when cows are grazed on pastures or given diets that do not contain soya bean meal.

\section{Conflict of interest}

The authors declare no conflict of interest.

\section{References}

Agriculture and Horticulture Development Board (AHDB), 2019. GB animal feed production. Available at: https://ahdb.org.uk/cerealsoilseeds/cereal-use-in-gb-animal-feed-production.

Arifin, B., Bono, A., Farm, Y.Y., Ling, A.L.L. and Fui, S.Y., 2009. Protein extraction from palm kernel meal. Journal of Applied Sciences 9: 2996-3004. https://doi.org/10.3923/jas.2009.2996.3004

Audsley, E. and Wilkinson, J.M., 2014. What is the potential for reducing national greenhouse gas emissions from crop and livestock production systems? Journal of Cleaner Production 73: 263-268. https://doi.org/10.1016/j.clepro.2014.01.066

Berger, K.G., 2003. Palm kernel oil. In: Caballero, B. (ed.) Encyclopedia of food sciences and nutrition. $2^{\text {nd }}$ edition. Academic Press, Cambridge, MA, USA, pp. 4322-4324.

Boateng, M., Okai, D.B., Baah, J. and Donkoh, A., 2008. Palm kernel cake extraction and utilisation in pig and poultry diets in Ghana. Livestock Research for Rural Development 20 (7). Available at: http://www.lrrd.org/lrrd20/7/boat20099.htm

Boutflour, R., 1967. The high yielding dairy cow. Crosby Lockwood \& Son Ltd, London, UK, 160 pp.

Castanheira, E.G. and Freire, F., 2013. Greenhouse gas assessment of soybean production: implications of land use change and different cultivation systems. Journal of Cleaner Production 54: 49-60. https:// doi.org/10.1016/j.jclepro.2013.05.026

Council for Agricultural Science and Technology (CAST), 1999. Animal agriculture and global food supply. Task Force Report no. 135. CAST, Ames, IA, USA, 92 pp.

CME Group 2020. Soybean crush reference guide. Available at: https:// www.cmegroup.com/education/files/soybean-crush-referenceguide.pdf.

Cunha, O.F.R., Neiva, J.N.M., Maciel, R.P., Restle, J., Araújo, V.L., Paiva, J and Miotto, F.R.C., 2013. Palm (Elaeis guineensis L.) kernel cake in diets for dairy cows. Semina: Ciências Agrárias, Londrina 34: 445-454. https://doi.org/10.5433/1678-0359.2013v34n1p445

Dias, F.N., 2010. Supplementation of palm kernel expeller to grazing dairy farms in New Zealand. PhD Thesis, Massey University, Palmerston North, New Zealand, 204 pp.

Dias, F.N., Burke, J.L., Pacheco, D. and Holmes, C.W., 2008. The effect of palm kernel expeller as a supplement for grazing dairy cows at the end of lactation. Proceedings of the New Zealand Society of Animal Production 68: 111-112.
European Commission, 2019. Oilseeds and protein crops statistics. EU trade for oilseeds and protein crops. Available at: https://ec.europa. eu/info/food-farming-fisheries/farming/facts-and-figures/markets/ overviews/market-observatories/crops/oilseeds-and-protein-crops_en.

Food and Agriculture Organisation (FAO), 2020. FAOSTAT. Production/yield quantities of soybeans in world, 2018. Available at: http://www.fao.org/faostat/en/\#data/QC/visualize.

Feedipedia, 2019. Feedipedia - animal feed resources information system. Available at: https://www.feedipedia.org.

FEFAC, 2017. Feed and food statistical yearbook 2017. Available at: https://www.fefac.eu/files/86004.pdf.

Florou-Paneri, P., Christaki, E., Giannenas, I., Bonos, E., Skoufos, I., Tsinas, A, Tzora, A. and Peng, J., 2014. Alternative protein sources to soybean meal in pig diets. Journal of Food, Agriculture \& Environment 12: 655-660.

Frank, B. and Swensson, C., 2002. Relationship between content of crude protein in rations for dairy cows and milk yield, concentration of urea in milk and ammonia emissions. Journal of Dairy Science 85: 1829-1838. https://doi.org/10.3168/jds.S0022-0302(02)74257-4 Garnsworthy, P.C., Saunders, N., Goodman, J.R., Marsden, M. and May, B., 2019. Rumen protected rapeseed expeller (NovaPro) as an alternative to soya bean meal in dairy cow diets. Advances in Animal Biosciences 10: 131.

Gunstone, F.D., 2003. Soy (Soya) bean oil. In: Caballero, B. (ed.) Encyclopedia of food sciences and nutrition. $2^{\text {nd }}$ edition. Academic Press, Cambridge, MA, USA, pp. 5375-5379.

Huhtanen, P., Hetta, M. and Swensson, C., 2011. Evaluation of canola meal as a protein supplement for dairy cows: a review and metaanalysis. Canadian Journal of Animal Science 91: 529-543. https:// doi.org/10.4141/CJAS2011-029

Iji, P.A., Toghyani, M., Ahiwe, E.U. and Omede, A.A., 2017. Alternative sources of protein for poultry nutrition. In: Applegate, T. (ed) Achieving sustainable production of poultry meat. vol. 2. Breeding and nutrition. Burleigh Dodds Science Publishing, Cambridge UK, pp. 237-270.

Jaworski, N.W., Shoulders, J., Gonzälez-Vega, J.C. and Stein, H.H., 2014. Effects of using copra meal, palm kernel expellers, or palm kernel meal in diets for weanling pigs. The Professional Animal Scientist 30: 243-251. https://doi.org/10.15232/S1080-7446(15)30108-X

Karlsson, J., Sporndly, R., Lindberg, M and Holtenius, K., 2018. Replacing human-edible feed ingredients with by-products increases net food production efficiency in dairy cows. Journal of Dairy Science 101: 7146-7155. https://doi.org/10.3168/jds.2017-14209

Kroes, H. and Kuepper, B., 2015. Mapping the soy supply chain in Europe. Profundo, Amsterdam, the Netherlands. Available at: http://assets.wnf.nl/downloads/mapping_the_soy_supply_chain_ in_europe_wnf_12_may_2015_final_1.pdf

Leinonen, I., Williams, A.G., Waller, A and Kyriazakis, I., 2013. Comparing the environmental impacts of alternative protein crops in poultry diets: the consequences of uncertainty. Agricultural Systems 121: 33-42. https://doi.org/10.1016/j.agsys.2013.06.008

Lucht, J.M., 2015. Public acceptance of plant biotechnology and GM crops. Viruses 7: 4254-4281. Available at: https://doi.org/10.3390/ v7082819

Meyer, G. and Schipani, A., 2019. Cargill admits loss of forest will persist. Financial Times, London, UK, 14 June 2019, p16. 
New York Declaration on Forests (NYDF), 2019. Progress on the New York Declaration on Forests: Goal 2 Assessment, Technical Annex to the Five-Year Assessment Report, September 2019. Available at: https://forestdeclaration.org/images/uploads/ resource/2019NYDFGoal2.pdf.

New Zealand Farmers Weekly, 2015. Limit palm kernel feed: Fonterra. 22 September 2015. Available at: https://farmersweekly.co.nz/\#.

OECD/FAO 2019. OECD-FAO agricultural outlook 2019-2018. Chapter 4. Oilseeds. Available at: http://www.fao.org/3/CA4076EN/ CA4076EN_Chapter4_Oilseeds.pdf.

Oliveira, R., Faria, M., Silva, R., Bezzera, L., Carvalho, G., Pinheiro, A., Simionato, J and Leão, A., 2015. Fatty acid profile of milk and cheese from dairy cows supplemented a diet with palm kernel cake. Molecules 20: 15434-15448. https://doi.org/10.3390/ molecules200815434

Opio, C., Gerber, P., Mottet, A., Falcucci, A., Tempio, G., Macleod, M., Vellinga, T., Henderson, B. and Steinfeld, H., 2013. Greenhouse gas emissions from ruminant supply chains - a global life cycle assessment. Food and Agriculture Organization of the United Nations (FAO), Rome, Italy, 191 pp.

Public Health England, 2019. McCance and Widdowson's composition of foods integrated dataset. PHE publication GW-285. Available at: https://www.gov.uk/government/publications/ compositionof-foods-integrated-dataset-cofid.

Round Table on Sustainable Palm Oil (RSPO), 2019. National Commitments. Available at: https://rspo.org/about/nationalcommitments.

Round Table on Responsible Soy Association (RRSA), 2019. Mission and vision. Available at: http://www.responsiblesoy.org/about-rtrs/ mission-and-vision/?lang=en

Schmidt, J.P., 2019. Pioneer crop insights: nitrogen fertilizer for soybean? Available at: https://www.pioneer.com/us/agronomy/ nitrogen_fertilizer_soybean.html.

Scott Wilson Ltd, 2006. Sustainable Commodities Case Study, Soya. Final Report, December 2006, 86 pp. Available at: https://tinyurl. com/yafr7smj.

Shurtleff, W. and Aoyagi, A., 2004. History of soy flour, grits, flakes and cereal-soy blends - part 1. Available at: http://www.soyinfocenter. com/HSS/flour1.php.

Statista, 2019a. Global production of vegetable oils. Available at: https://www.statista.com/statistics/263978/global-vegetable-oilproduction-since-2000-2001/.

Statista, 2019b. Total milk production in the United Kingdom (UK), 2001/02 to 2017/18. Available at: https://www.statista.com/ statistics/298770/milk-production-in-the-united-kingdom-uk/.

Stein, H.H., Casas, G.A., Abelilla, J.J., Liu, Y. and Sulabo, R.C., 2015. Nutritional value of high fiber co-products from the copra, palm kernel and rice industries in diets fed to pigs. Journal of Animal Science and Biotechnology 6: 56. Available at: https://doi. org/10.1186/s40104-015-0056-6

Traynham, T.L., 2006. Evaluation of extruded-expelled low fat soybean flour in flour blends and the effects on bread and dough development. PhD Thesis, Iowa State University, Ames, IA, USA, 96 pp. Available at: https://pdfs.semanticscholar.org/2217/668c8d 77da0f91e62cf3da7039ba081b9ee9.pdf.
Van Gelder, J.W and Dros, J.M., 2002. Corporate actors in the South American soy production chain. World Wide Fund for Nature, Switzerland, 90 pp. Available at: https://tinyurl.com/yd45ux84.

Van Wyngaard, J.D.V and Meeske, R., 2017. Palm kernel expeller increase milk fat content when fed to grazing dairy cows. South African Journal of Animal Science 47: 219-230. https://doi. org/10.4314/sajas.v47i2.14

Van Zanten, H.H.E., Bikker, P., Mollenhorst, H. and Meerburg, B.G., 2015. Environmental impact of replacing soybean meal with rapeseed meal in diets for finishing pigs. Animal 9: 1866-1874. https://doi.org/10.1017/S1751731115001469

Voglmeier, K., Six, J., Jocher, M and Ammann, C., 2019. Grazingrelated nitrous oxide emissions: from patch scale to field scale. Biogeosciences 16: 1685-1703. https://doi.org/10.5194/bg-161685-2019

White, G.A., Smith, L.A., Houdijk, J.G.M., Homer, D., Kyriazakis, I and Wiseman, J., 2015. Replacement of soya bean meal with peas and faba beans in growing/finishing pig diets: effect on performance, carcass composition and nutrient excretion. Animal Feed Science and Technology 209: 202-210. https://doi.org/10.1016/j. anifeedsci.2015.08.005

Whiting, T., 2019. What milk should you buy to reduce your environmental impact? Available at: https://medium.com/@tabitha. whiting/what-milk-should-you-buy-to-reduce-your-environmentalimpact-e0489153e3b8.

Wilkinson, J.M., 2011. Re-defining efficiency of feed use by livestock. Animal 5: 1014-1022. https://doi.org/10.1017/S175173111100005X

Wilkinson, J.M. and Audsley, E., 2013. Options from life-cycle analysis for reducing greenhouse gas emissions from crop and livestock production systems. International Journal of Agricultural Management 2: 70-80. https://doi.org/10.5836/ijam/2013-02-02

Wilkinson, J.M. and Garnsworthy P.C., 2016. Dietary options to reduce the environmental impact of milk production. Journal of Agricultural Science 155: 334-347. https://doi.org/10.1017/S0021859616000757

Wilkinson, J.M. and Lee, M.R.F., 2018. Use of human-edible animal feeds by ruminant livestock. Animal 12: 1735-1743. https://doi. org/10.1017/S175173111700218X

Wilkinson, J.M. and Waldron, L.A., 2017. Feeding strategies for reducing nitrogen excretion in New Zealand milk production. Journal of Applied Animal Nutrition 5: e10. https://doi.org/10.1017/ jan.2017.8

Wilkinson J.M., Allen J.D., Tunnicliffe R., Smith M., and Garnsworthy P.C., 2014. Variation in composition of pre-grazed pasture herbage in the United Kingdom, 2006-2012. Animal Feed Science and Technology 196: 139-144. https://doi.org/10.1016/ j.anifeedsci.2014.07.001

Wilkinson, J.M. Lee, M.R.F. Rivero, M.J. and Chamberlain, A.T., 2020. Grazing dairy cows on temperate pastures: some challenges and opportunities. Grass and Forage Science 75: 1-17. https://doi. org/10.1111/gfs.12458

Young, R.H., 2017. Are dairy cows and livestock behind the growth of soya in South America? Available at: https://sustainablefoodtrust. org/articles/dairy-cows-livestock-behind-growth-soya-southamerica/. 